\title{
Efficient Remyelination Requires DNA Methylation
}

\author{
(1) Sarah Moyon, ${ }^{1, *}$-Dan Ma, ${ }^{4, *}$ Jimmy L. Huynh,, ${ }^{1,2}$ DDavid J.C. Coutts, ${ }^{4}$ (DChao Zhao, ${ }^{4}$ \\ (D)Patrizia Casaccia, ${ }^{1,2,3}$ and Robin J.M. Franklin ${ }^{4}$
}

\section{DOI:http://dx.doi.org/10.1523/ENEURO.0336-16.2017}

${ }^{1}$ Department of Neuroscience, Icahn School of Medicine at Mount Sinai, New York, NY 10029, ${ }^{2}$ Department of Genetics and Genomic Sciences, Icahn School of Medicine at Mount Sinai, New York, NY 10029, ${ }^{3}$ Neuroscience Initiative Advanced Science Research Center, CUNY, New York, NY 10031, and ${ }^{4}$ Wellcome Trust-Medical Research Council Cambridge Stem Cell Institute and Department of Clinical Neurosciences, University of Cambridge, Cambridge, CB2 OAH, UK

\section{Visual Abstract}

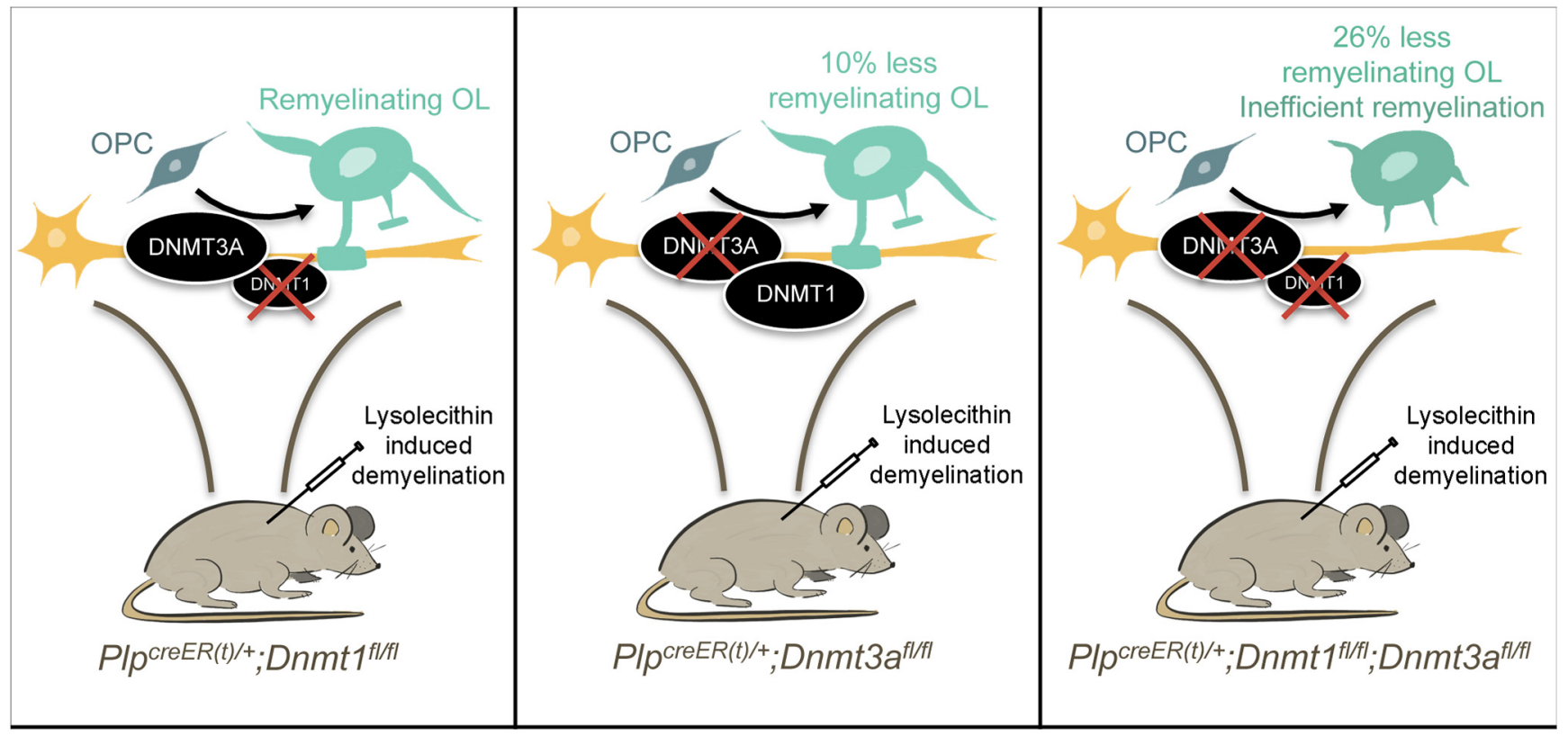

Oligodendrocyte progenitor cells (OPCs) are the principal source of new myelin in the central nervous system. A better understanding of how they mature into myelin-forming cells is of high relevance for remyelination. It has recently been demonstrated that during developmental myelination, the DNA methyltransferase 1 (DNMT1), but not DNMT3A, is critical for regulating proliferation and differentiation of OPCs into myelinating oligodendrocytes

\section{Significance Statement}

The regenerative therapy of enhancing remyelination is the subject of much current investigation for a number of central nervous system disorders. However, its mechanisms remain incompletely understood. A recent study identified a distinct role of the DNA methyltransferase 1 (DNMT1) in developmental myelination; here we report a dominant role for DNMT3A in adult remyelination after lysolecithin-induced demyelination. Overall, this is of high relevance, as it indicates that neonatal and adult oligodendrocyte progenitor cells might be characterized by distinct epigenetic landscapes that may need to be taken into consideration for the development of future therapeutic strategies. 
(OLs). However, it remains to be determined whether DNA methylation is also critical for the differentiation of adult OPCs during remyelination. After lysolecithin-induced demyelination in the ventrolateral spinal cord white matter of adult mice of either sex, we detected increased levels of DNA methylation and higher expression levels of the DNA methyltransferase DNMT3A and lower levels of DNMT1 in differentiating adult OLs. To functionally assess the role of DNMT1 and DNMT3 in adult OPCs, we used mice with inducible and lineage-specific ablation of Dnmt3a and/or Dnmt1 (i.e., Plp-creER(t);Dnmt3a-flox, Plp-creER(t);Dnmt1-flox, Plp-creER(t);Dnmt1-flox;Dnmt3aflox). Upon lysolecithin injection in the spinal cord of these transgenic mice, we detected defective OPC differentiation and inefficient remyelination in the Dnmt3a null and Dnmt1/Dnmt3a null mice, but not in the Dnmt1 null mice. Taken together with previous results in the developing spinal cord, these data suggest an agedependent role of distinct DNA methyltransferases in the oligodendrocyte lineage, with a dominant role for DNMT1 in neonatal OPCs and for DNMT3A in adult OPCs.

Key words: Adult oligodendrocyte progenitor cells; DNA methylation; remyelination

\section{Introduction}

In demyelinating disorders, such as multiple sclerosis (MS), loss of myelin sheaths disturbs axonal conduction and trophic support, eventually leading to irreversible axonal loss and disease progression (Trapp et al. 1998; Nave and Trapp, 2008; Franklin et al. 2012). Remyelination, which restores myelin sheaths to demyelinated axons and thereby restores both axonal function and protection, is regarded as a promising way to prevent disease progression (Dubois-Dalcq et al. 2008; Franklin and FfrenchConstant, 2008). Oligodendrocyte progenitor cells (OPCs) have been identified as the main source for new myelin formation in the adult central nervous system (CNS; Zawadzka et al. 2010). Therefore, a better understanding of the molecular mechanism regulating their differentiation into myelin-forming cells is highly desirable. It has been proposed that after demyelination, adult OPC differentiation recapitulates developmental myelination to a large extent, and the expression of well-established differentiation regulatory transcription factors (e.g., Myrf, Nkx2.2, Tcf4, Sox2) has been shown to change during remyelination (Fancy et al. 2004, 2009; Koenning et al. 2012; Moyon et al. 2015; Zhao et al. 2015).

The importance of posttranslational histone modifications during remyelination has previously been reported (Shen et al. 2008). Recently, it has been shown that DNA methylation mediated by the DNA methyltransferase

Received November 7, 2016; accepted January 31, 2017; First published March 20, 2017.

The authors declare no competing financial interests.

Author contributions: P.C. and R.J.M.F. designed the research; D.M., S.M., J.L.H., D.J.J.C., and C.Z. performed the research; D.M., S.M., C.Z., P.C., and R.J.M.F. analyzed the data; S.M. wrote the paper with input from other authors. This work was supported by NIH-R37NS42925-14 to P.C., NIH-F31NS077504 Fellowship to J.L.H., postdoctoral fellowships from the Paralyzed Veterans of America (3061) and National Multiple Sclerosis Society (FG-1507-04996) to S.M., a program grant from the UK Multiple Sclerosis Society (R.J.M.F., C.Z.) and a core support grant from the Wellcome Trust and MRC to the Wellcome Trust - Medical Research Council Cambridge Stem Cell Institute (R.J.M.F.).

${ }^{*}$ S.M. and D.M. are co-first authors.

Correspondence should be addressed to either of the following: Sarah Moyon. E-mail: sarah.moyon@mssm.edu; or Robin J. M. Franklin. E-mail: rjf1000@cam.ac.uk.

DOI:http://dx.doi.org/10.1523/ENEURO.0336-16.2017

Copyright @ 2017 Moyon et al.

This is an open-access article distributed under the terms of the Creative Commons Attribution 4.0 International license, which permits unrestricted use, distribution and reproduction in any medium provided that the original work is properly attributed.
DNMT1 is essential for developmental myelination, where it controls the transition from the proliferative OPC stage to differentiating oligodendrocytes (OLs; Moyon et al. 2016). In this study, we asked whether similar epigenetic mechanisms might be involved in the regulation of adult OPC differentiation during remyelination. Transcriptomic data gathered from laser microdissected regions of CNS white matter at various times after acute experimentally induced demyelination indicate that the expression of Dnmt1 and Dnmt3a are differentially regulated during remyelination (Huang et al. 2011). Both enzyme levels were higher at 5 days post-lesion (dpl), during the early stages of remyelination, and lower at 14 and $28 \mathrm{dpl}$, suggesting that DNA methylation might also play a role in the transition from adult OPCs to myelinating OLs. A recent study has previously reported genome-wide DNA methylation changes in postmortem brain samples from MS patients compared with controls, suggesting an underlying dysregulation of DNA methylation in MS brains (Huynh et al. 2014).

This study directly addresses the role of DNA methylation in oligodendroglial lineage cells during remyelination in the adult spinal cord. Here we show that DNA methylation and DNA methyltransferase levels are differentially regulated during remyelination. We use lineage-specific inducible genetic ablation of Dnmt1 or Dnmt3a in adult mice to address the functional relevance of DNA methylation perturbations for adult OPC differentiation and the efficiency of remyelination after experimentally induced demyelination.

\section{Materials and Methods}

\section{Animals}

All experiments were performed according to institutional animal care and use committee-approved protocols and mice were maintained in a temperature- and humiditycontrolled facility on a 12-h light-dark cycle with food and water ad libitum. Dnmt $1^{f / f f l}$ (Fan et al. 2001; Jackson-Grusby et al. 2001, RRID:MMRRC_014114-UCD) and Dnmt3a $a^{\text {fl/fl }}$ (Kaneda et al. 2004, RRID:MGI:3718448) mice on a C57BL/6 background were crossed with Plp-creER(t) (The Jackson Laboratory, RRID:MGI:3696409; Doerflinger et al. 2003).

\section{Lysolecithin injections}

Injections were conducted in the ventrolateral spinal cord white matter of 8-week-old animals of either sex, as previously described (Fancy et al. 2009). Briefly, anesthe- 
Table 1. Statistical analysis

\begin{tabular}{|c|c|c|c|}
\hline $\begin{array}{l}\text { Code } \\
\text { a (Fig. 1C) }\end{array}$ & $\begin{array}{c}\text { Data structure } \\
\text { Normal distribution, equal variances }\end{array}$ & $\begin{array}{l}\text { Type of test } \\
\text { ANOVA and Bonferroni posttests }\end{array}$ & $\begin{array}{c}95 \% \mathrm{Cl} \\
108.6 \text { to } 272.7,-27.42 \text { to } 136.7 \text { and }-73.69 \text { to } 90.40\end{array}$ \\
\hline b (Fig. 1D) & Normal distribution, equal variances & ANOVA and Bonferroni posttests & $\begin{array}{l}51.11 \text { to } 98.17 \text { and } 11.76 \text { to } 58.82(5 \mathrm{dpl}) ; 33.78 \text { to } 80.84 \text { and } \\
-11.49 \text { to } 35.57 \text { ( } 14 \mathrm{dpl}) ; 25.89 \text { to } 72.95 \text { and }-14.29 \text { to } 32.77 \\
\text { (21dpl) }\end{array}$ \\
\hline${ }^{\mathrm{C}}$ (Fig. 1F) & Normal distribution, equal variances & ANOVA and Bonferroni posttests & 45.42 to $116.2,176.9$ to 247.7 and 133.9 to 204.7 \\
\hline d (Fig. 1G) & Normal distribution, equal variances & ANOVA and Bonferroni posttests & $\begin{array}{l}-2.914 \text { to } 37.65 \text { and } 60.67 \text { to } 101.2(5 \mathrm{dpl}) ;-5.602 \text { to } 34.96 \\
\text { and } 77.53 \text { to } 118.1 \text { (14dpl); }-13.63 \text { to } 26.93 \text { and } 53.74 \text { to } 94.30 \\
\text { ( } 21 \mathrm{dpl})\end{array}$ \\
\hline${ }^{\mathrm{e}}$ (Fig.1l) & Normal distribution, equal variances & ANOVA and Bonferroni posttests & $\begin{array}{l}-73.29 \text { to }-34.94,-70.07 \text { to }-31.72 \text { and }-85.01 \text { to }-46.66 \text { (low); } \\
19.25 \text { to } 57.60,8.444 \text { to } 46.79 \text { and } 16.22 \text { to } 54.56 \text { (medium); } \\
-4.294 \text { to } 34.05,4.099 \text { to } 42.45,11.27 \text { to } 49.62 \text { (high) }\end{array}$ \\
\hline f (Fig. 2B) & Normal distribution, equal variances & Student's $t$-test & 201.1 to $231.7\left(\mathrm{OLIG}^{+}\right), 191.3$ to $215.4\left(\mathrm{CC}^{+}{ }^{+}\right)$ \\
\hline (Fig. 2D) & Normal distribution, equal variances & Student's $t$-test & 210.2 to $205.7\left(\mathrm{OLIG}_{2}^{+}\right), 203.9$ to $189.2\left(\mathrm{CC}^{+}{ }^{+}\right)$ \\
\hline (Fig. 2F) & Normal distribution, equal variances & Student's $t$-test & 178.2 to $144.9\left(\mathrm{OLIG}^{+}\right), 165.7$ to $136.2\left(\mathrm{CC}^{+}{ }^{+}\right)$ \\
\hline i $($ Fig.2H) & Normal distribution, equal variances & ANOVA and Bonferroni posttests & 70.83 to 72.29 (low); 15.67 to 13.36 (medium); 13.50 to 14.35 (high) \\
\hline j (Fig.2l) & Normal distribution, equal variances & ANOVA and Bonferroni posttests & 77.96 to 65.61 (low); 15.85 to 23.22 (medium); 6.186 to 11.17 (high) \\
\hline k (Fig.2J) & Normal distribution, equal variances & ANOVA and Bonferroni posttests & 67.91 to 58.45 (low); 21.32 to 31.39 (medium); 10.77 to 10.16 (high) \\
\hline ' (Fig. 3B) & Normal distribution, equal variances & Student's $t$-test & $\begin{array}{l}-307.8 \text { to } 246.4\left(\mathrm{OLIG}_{2}^{+}\right),-249.9 \text { to } 105.2\left(\mathrm{CC}^{+}\right) \text {and }-16.51 \text { to } \\
17.07\left(\mathrm{CC} 1^{+} / \mathrm{OLIG}^{+}\right)\end{array}$ \\
\hline m (Fig. 3D) & Normal distribution, equal variances & Student's $t$-test & $\begin{array}{l}-341.1 \text { to } 431.1\left(\mathrm{OLIG}_{2}^{+}\right), 13.87 \text { to } 270.7\left(\mathrm{CC} 1^{+}\right) \text {and } 2.758 \text { to } \\
\text { 17.22 }\left(\mathrm{CC} 1^{+} / \mathrm{OLIG}^{+}\right)\end{array}$ \\
\hline n (Fig. 3F) & Normal distribution, equal variances & Student's $t$-test & $\begin{array}{l}-275.5 \text { to } 52.4\left(\mathrm{OLIG}^{+}\right), 12.91 \text { to } 264.6\left(\mathrm{CC}^{+}{ }^{+}\right) \text {and } 17.64 \text { to } \\
\quad 38.55\left(\mathrm{CC} 1^{+} / \mathrm{OLIG}^{+}\right)\end{array}$ \\
\hline${ }^{\circ}$ (Fig. 3G) & Normal distribution, equal variances & Student's $t$-test & $\begin{array}{l}36.15 \text { to } 226.8 \text { (DNMT1) and }-136.3 \text { to } 15.88 \text { (DNMT3A); }-134.3 \text { to } \\
-21.63 \text { (DNMT1) and } 48.69 \text { to } 246.2 \text { (DNMT3A); } 51.76 \text { to } 317.0 \\
\text { (DNMT1) and } 106.9 \text { to } 307.9 \text { (DNMT3A) }\end{array}$ \\
\hline$P$ (Fig.4B) & Normal distribution, equal variances & ANOVA and Bonferroni posttests & 22.94 to 25.45 (low); 59.72 to 59.83 (medium); 17.33 to 14.72 (high) \\
\hline q (Fig.4D) & Normal distribution, equal variances & ANOVA and Bonferroni posttests & 22.71 to 31.26 (low); 58.99 to 55.91 (medium); 18.30 to 12.83 (high) \\
\hline r (Fig.4F) & Normal distribution, equal variances & ANOVA and Bonferroni posttests & 21.26 to 37.88 (low); 61.43 to 49.48 (medium); 17.31 to 12.64 (high) \\
\hline s (Fig. 5B) & Nonnormal distribution & Nonparametric Mann Whitney test & 2.648 to 11.35 and 1.362 to 7.838 \\
\hline t (Fig. 5C) & Normal distribution, unequal variances & $\begin{array}{l}\text { Student's } t \text {-test with Welch's } \\
\text { correction }\end{array}$ & -0.005297 to 0.005700 \\
\hline u (Fig. 5E) & Nonnormal distribution & Nonparametric Mann Whitney test & 1.823 to 11.38 and 2.191 to 9.142 \\
\hline v (Fig. 5F) & Normal distribution, unequal variances & $\begin{array}{l}\text { Student's } t \text {-test with Welch's } \\
\text { correction }\end{array}$ & -0.001182 to 0.01204 \\
\hline$\times$ (Fig. $5 \mathrm{H})$ & Nonnormal distribution & Nonparametric Mann Whitney test & -1.006 to 9.256 and 2.886 to 6.864 \\
\hline y (Fig. 5G) & Normal distribution, unequal variances & $\begin{array}{l}\text { Student's } t \text {-test with Welch's } \\
\text { correction }\end{array}$ & -0.01370 to -0.003870 \\
\hline
\end{tabular}

sia was induced and maintained with inhalational isoflurane/oxygen. The vertebral column was fixed between metal bars on stereotaxic apparatus. The spinal vertebra was exposed, tissue was cleared overlying the intervertebral space, and the dura was pierced. A pulled-glass needle was advanced through the spine, at an angle of $70^{\circ}$, and $1 \mu \mathrm{l}$ of $1 \%$ lysolecithin (Sigma-Aldrich L4129) was slowly injected into the ventrolateral white matter. Mice were sutured and kept in a warm chamber during recovery.

\section{Tamoxifen injections}

4-Hydroxytamoxifen (Sigma-Aldrich T56-48) was dissolved at $40 \mathrm{mg} / \mathrm{ml}$ in $10 \%$ ethanol and $90 \%$ corn oil (Sigma-Aldrich C8267) for $4 \mathrm{~h}$ at $37^{\circ} \mathrm{C}$ with rotation, and $10 \mathrm{mg}$ was administered by gavage to each mouse at days 3,5 , and 7 (for $14 \mathrm{dpl}$ analysis) or at days 5,7 , and 9 (21 dpl analysis) after lysolecithin injection (day 0).

\section{Immunohistochemistry}

For immunohistochemistry, animals were perfused at 5, 14 , or $21 \mathrm{dpl}$ with $4 \%$ paraformaldehyde and postfixed overnight in the same solution at $4^{\circ} \mathrm{C}$. Spinal cords were dissected, cryoprotected in sucrose solutions, and frozen embedded in OCT. Immunohistochemistry was performed on $12-\mu \mathrm{m}$ cryostat sections. Antigen retrieval was performed for 5-methylcytosine $(5 \mathrm{mC})$ staining by incu- bating slides in subboiling $\left(94^{\circ} \mathrm{C}\right)$ citrate buffer $(\mathrm{pH} 6.0)$ for 15 min. Slides were incubated in blocking buffer $(5 \%$ normal donkey serum in PBS/Triton X-100 0.3\%) for $1 \mathrm{~h}$ at room temperature and then overnight at $4^{\circ} \mathrm{C}$ with the primary antibodies diluted in a similar blocking buffer $(5 \%$ normal donkey serum in PBS/Triton X-100 0.3\%). After rinsing with PBS $1 \times$, sections were incubated with the Alexa Fluor secondary antibodies and then washed with PBS $1 \times$. Cell nuclei were counterstained with DNA fluorescent dye Hoechst 33342 (Sigma B2261) in PBS. Stained tissue or cells were coverslipped in FluorSave mounting medium (Millipore 345789) and examined on a Zeiss Axio Observer fluorescence microscope. To quantify the data generated by immunohistochemical staining, counts were undertaken by an observer who was blinded to the experimental group from which the sample being analyzed was taken. Counts were made throughout the entire lesion area which was scanned using the $20 \times$ objective of the fluorescence microscope. Labeled cells were manually counted from the images captured under the same exposure conditions. AxioVision Rel4.8 software (RRID:SCR_002677) was used for colocalized color identification and area measurement. Quantification of total cell number, as defined by nuclear (DAPI) staining, was assessed both within the lesion area and within the corresponding region of white matter in unlesioned tissue. 
A

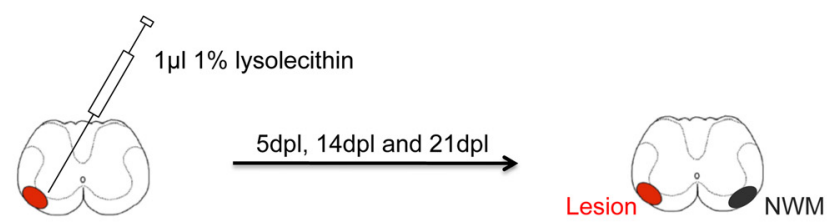

B
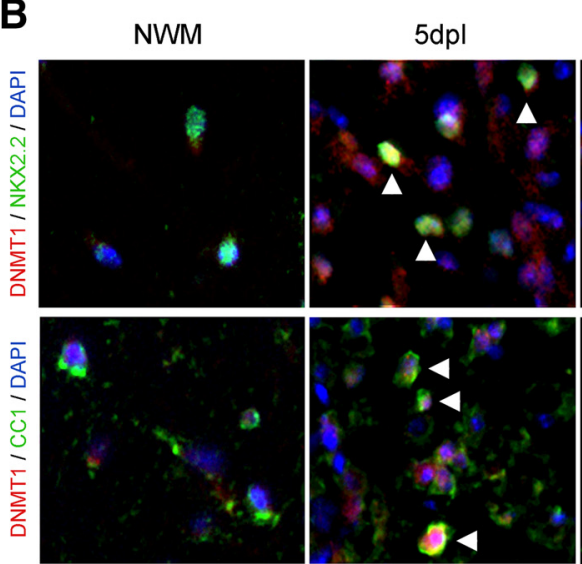

E

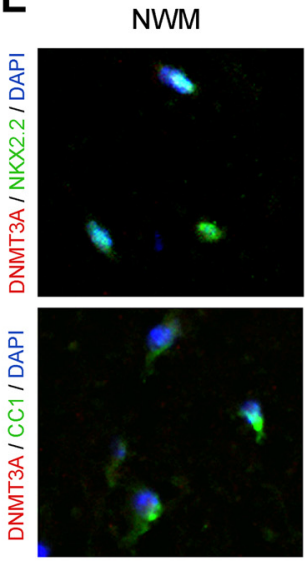

H
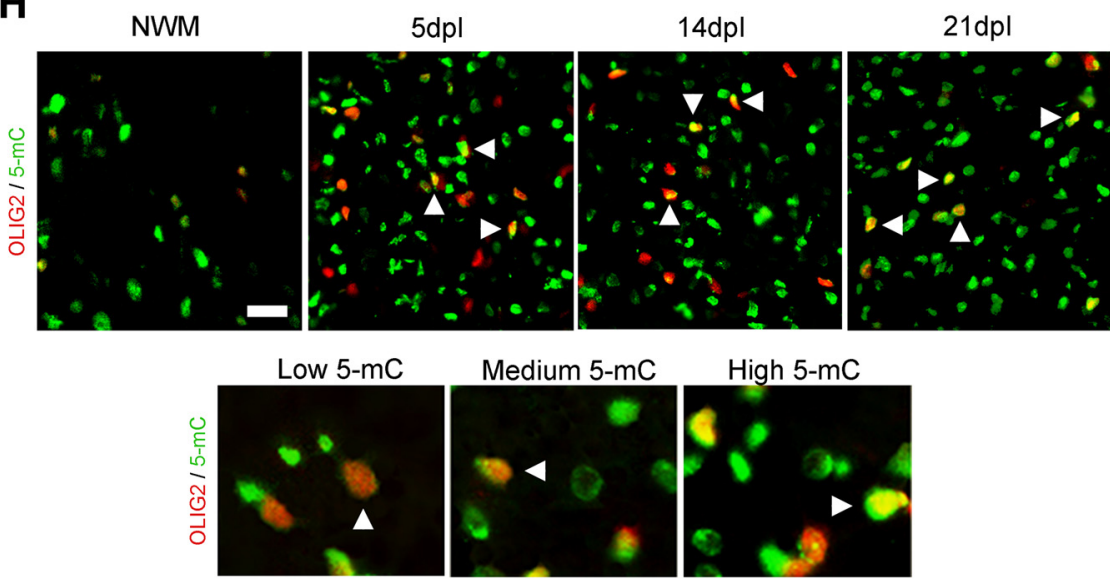

Medium 5-mC
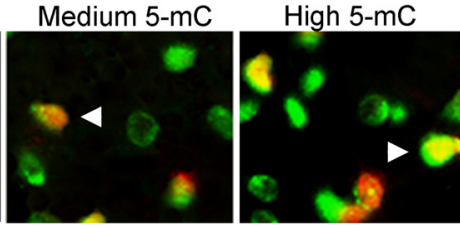

Figure 1. DNA methyltransferases are differently expressed in adult OPCs during remyelination. $\boldsymbol{A}$, Schematic of the lysolecithininduced focal demyelination and of the area of NWM used for quantification. $\boldsymbol{B}$, Representative DNMT1, NKX2.2, and CC1 stainings in NWM and at 5, 14, and $21 \mathrm{dpl}$ (white arrowheads indicate double-positive cells). C, Quantification of the number of double DNMT1 ${ }^{+}$ and NKX2.2 $2^{+}$cells at 5,14 , and $21 \mathrm{dpl}$, compared with NWM ${ }^{a} . \boldsymbol{D}$, Quantification of the percentage of double DNMT1 ${ }^{+}$and NKX2.2 ${ }^{+}$ or $\mathrm{CC}^{+}$cells at 5,14 , and $21 \mathrm{dpl}$, compared with NWM ${ }^{\mathrm{b}}$. E, Representative DNMT3A, NKX2.2, and CC1 stainings in NWM and at 
continued

5,14 , and $21 \mathrm{dpl}$ (white arrowheads indicate double-positive cells). $\boldsymbol{F}$, Quantification of the number of double DNMT3A ${ }^{+}$and $\mathrm{CC} 1^{+}$ cells at 5,14 , and $21 \mathrm{dpl}$, compared with $\mathrm{NWM}^{\mathrm{C}}$. G, Quantification of the percentage of double DNMT3A ${ }^{+}$and NKX2.2 ${ }^{+}$or $\mathrm{CC}^{+}{ }^{+}$cells at 5, 14, and $21 \mathrm{dpl}$, compared with NWM ${ }^{d} . \boldsymbol{H}$, Representative $5 \mathrm{mC}$ and OLIG2 staining in NWM and at 5, 14, and $21 \mathrm{dpl}$ (white arrowheads indicate high- $5 \mathrm{mC}^{+} / \mathrm{OLIG} 2^{+}$cells). Representative low-, medium-, and high-5mC cells are shown below. I, Quantification of low-, medium-, and high-5mC levels in OLIG2 ${ }^{+}$cells at 5, 14, and $21 \mathrm{dpl}$, compared with NWM ${ }^{\mathrm{e}}$. Scale bar $=20 \mu \mathrm{m}$. Data are mean \pm SEM. $n=4-6$ animals, three sections per animal. $* p<0.05, * * p<0.01, * * * p<0.001$ (ANOVA).

To assess the levels of $5 \mathrm{mC}$ in OLIG2 ${ }^{+}$cells, arbitrarily defined as being either low, medium, or high, a macro was created in ImageJ (RRID:SCR_003070) that first localized the $\mathrm{OLIG}_{2}{ }^{+}$(red) nuclei and then measured the intensity of the $5 \mathrm{mC}$ (green) staining within the nuclear area. The intensity value was then normalized by deducting the background staining intensity. For all quantifications, a minimum of three sections of $12-\mu \mathrm{m}$ thickness from each lesion randomly chosen from $n=4-6$ mice was examined. The percentage or density of cells was determined per mouse. The average and standard error was then calculated for each group using GraphPad Prism (GraphPad, RRID:SCR_002798).

\section{Antibodies}

Primary antibodies used are: mouse anti-5mC (Abcam, ab10805, RRID:AB_442823, 1:200), mouse anti-CC1/APC (Millipore OP80, RRID:AB_2057371, 1:300), rabbit antiDNMT1 (Abcam, ab19905, RRID:AB_731983, 1:1000), rabbit anti-DNMT3A (Santa Cruz, sc-20703, RRID: AB_2093990, 1:500), mouse anti-NKX2.2 (Developmental Studies Hybridoma Bank, University of lowa, lowa City, IA, 1:100), and rabbit anti-OLIG2 (Millipore, ab9610, RRID: AB_10141047, 1:1000). Alexa Fluor-conjugated secondary antibodies (1:5000) were used (Invitrogen).

\section{Electron microscopy}

For electron microscopy, animals were perfused at 21 $\mathrm{dpl}$ with $4 \%$ glutaraldehyde in PBS containing $0.4 \mathrm{~mm}$ $\mathrm{CaCl}_{2}$ and postfixed in the same solution at $4^{\circ} \mathrm{C}$. The spinal cord was coronally sliced at 1-mm thickness and treated with $2 \%$ osmium tetroxide overnight before being subjected to a standard protocol for epoxy resin embedding (Zhao et al. 2008) Tissues were sectioned at $1 \mu \mathrm{m}$ and stained with toluidine blue. Remyelination ranking, in which lesions with the greatest extent of remyelination were assigned the highest rank value, was performed under light microscopy (lbanez et al. 2003). Ultrathin sections of the lesion site were cut onto copper grids and stained with uranyl acetate before being examined with a Hitachi $\mathrm{H}-600$ transmission electron microscope. G-ratio was quantified on $50-\mathrm{nm}$ sections on a minimum of 70 myelinated and remyelinated axons per animal, three to five mice for each genotype.

\section{Statistical analysis}

All statistical analyses were done using GraphPad Prism (Table 1). Unpaired Student's $t$ test was used for every two datasets with equal variances and for which data followed a normal distribution. If data were not normally distributed, nonparametric Mann-Whitney test was used (for rankings analysis), and if the variances were significantly different, the Welch's correction was applied (for g-ratio analysis). Two-way ANOVA was used to compare three or more sets of data. For all graphs, error bars are mean \pm SEM.

\section{Results}

\section{DNA methyltransferases are differently expressed in adult OPCs during remyelination}

To begin characterizing the role of DNA methylation in the oligodendroglial lineage during remyelination, we performed lysolecithin injections in the ventrolateral spinal cord of 8-week-old C57BL/6 mice and perfused them at 5,14 , and $21 \mathrm{dpl}$, to access DNMT1, DNMT3A, and 5mC expression in OPCs and OLs (Fig. 1A). The number of NKX2.2 ${ }^{+}$oligodendroglial cells strongly expressing DNMT1, while abundant at $5 \mathrm{dpl}$ when compared with levels in surrounding intact nonlesioned white matter (NWM), decreased between 5 and $21 \mathrm{dpl}$ (Fig. 1B, C). Costaining of DNMT1 with CC1, a marker of mature OLs, or NKX2.2, a marker of OPCs, revealed that within the $\mathrm{CC} 1^{+}$population the enzyme was expressed in $35.3 \pm 6.3 \%$ ( $5 \mathrm{dpl}), 12.0 \pm$ $5.4 \%$ (14 dpl), and $9.2 \pm 5.6 \%$ ( $21 \mathrm{dpl})$ of cells, whereas in the NKX2.2 $2^{+}$population, it was expressed in $74.6 \pm$ $5.3 \%$ (5 dpl), $57.3 \pm 11.1 \%$ (14 dpl), and $49.4 \pm 4.0 \%$ (21 dpl) of cells (Fig. $1 B, D$ ). In contrast, the distribution of DNMT3A showed a different pattern, being strongly expressed by $\mathrm{CC}^{+}$cells and increased from 5 to $14 \mathrm{dpl}$ (Fig. $1 E, F$ ): DNMT3A was expressed in $81.0 \pm 7.6 \%$ (5 dpl), $97.8 \pm 1.9 \%$ (14 dpl), and $74.0 \pm 9.3 \%$ (21dpl) of the $\mathrm{CC}^{+} \mathrm{OL}$ population and in only $17.4 \pm 3.8 \%(5 \mathrm{dpl})$, $14.7 \pm 4.0 \%(14 \mathrm{dpl})$, and $6.7 \pm 4.4 \%(21 \mathrm{dpl})$ of the NKX2.2 $2^{+}$population (Fig. 1E, G). These data indicate distinct patterns of expression, with DNMT1 mainly expressed by adult OPCs during the early stages of remyelination, and DNMT3A mainly detected in differentiated adult OLs that appear in the later stages of remyelination.

We also quantified $5 \mathrm{mC}$ expression levels in oligodendroglial cells. Because of species similarities in the $5 \mathrm{mC}$ antibodies and those we had used for the OL lineage, we combined $5 \mathrm{mC}$ staining with the pan-OL lineage marker OLIG2. This revealed a decreased proportion of lowmethylated and increased proportion of medium- and high-methylated oligodendroglial cells during remyelination (Fig. $1 H, I$ ). Hypermethylation in OLIG2 ${ }^{+}$cells was already evident starting at $5 \mathrm{dpl}$ (Fig. 1/).

\section{Ablation of DNMT3A and both DNMT1 and 3A impairs oligodendrocyte differentiation during remyelination}

To address more specifically the functional role of DNA methylation in adult OPCs during remyelination, we 
A

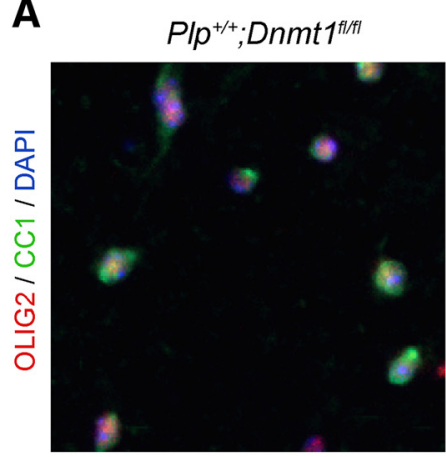

C

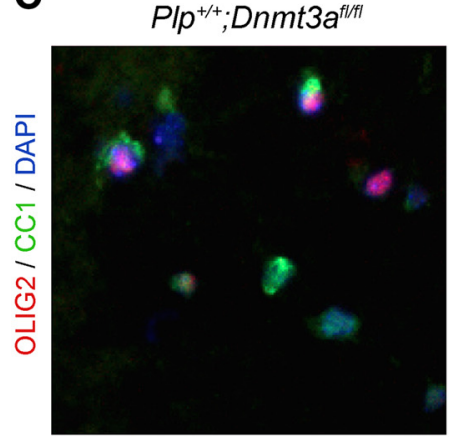

E

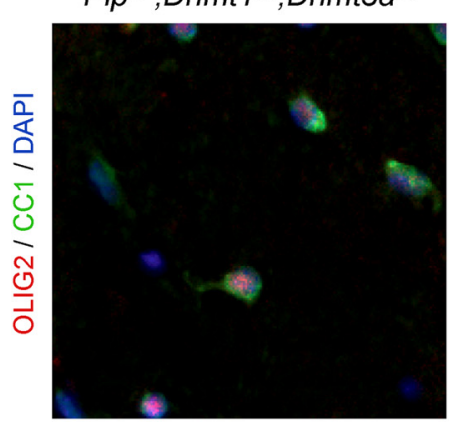

G

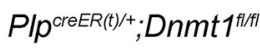

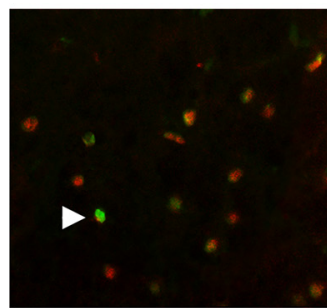

H

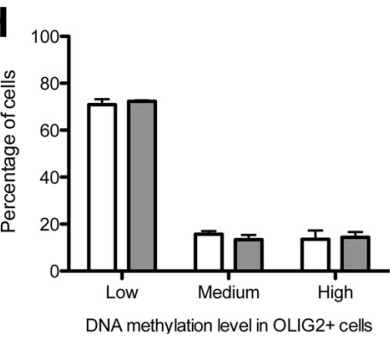

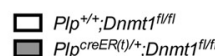

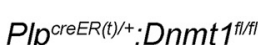

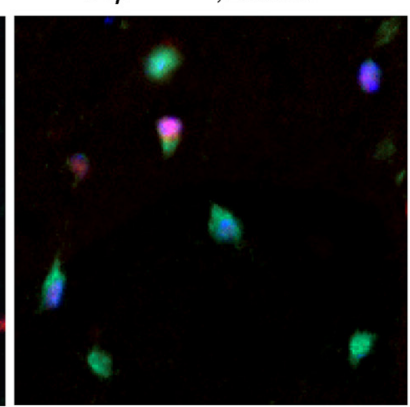

Plp ${ }^{\text {creER(t)/+*} ; D n m t 3 a a^{f / f t}}$

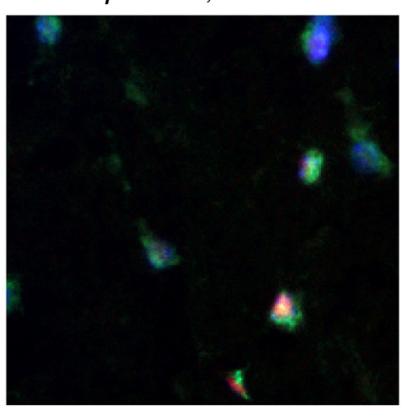

\section{$\mathbf{F}$

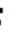
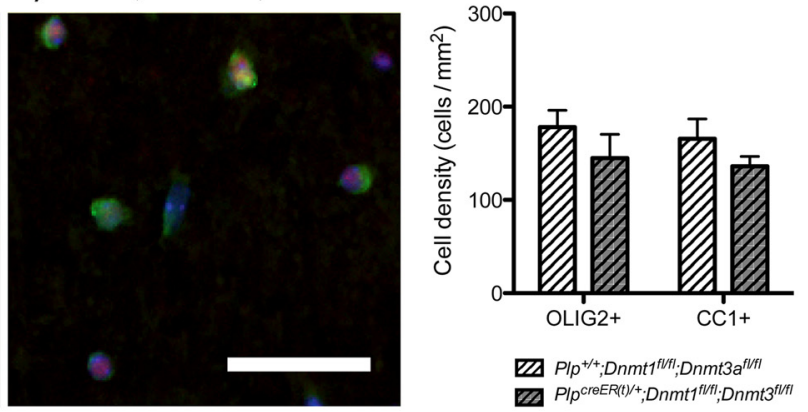

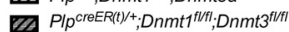

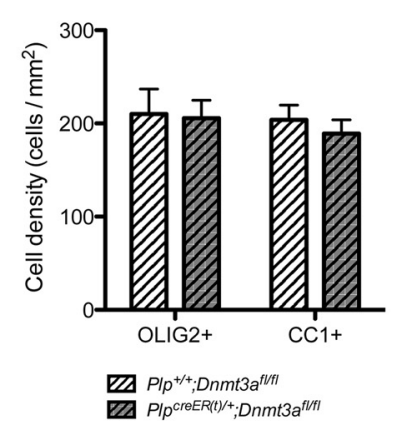

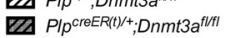

[2] $P / p^{+/+} ; D n m t t^{f l / f I}$

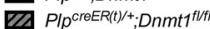

D

Plp ${ }^{\operatorname{CreER}(t) /+} ;$ Dnmt $1^{f|/ f|} ; D n m t 3 a^{f|f|}$

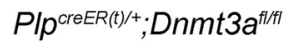
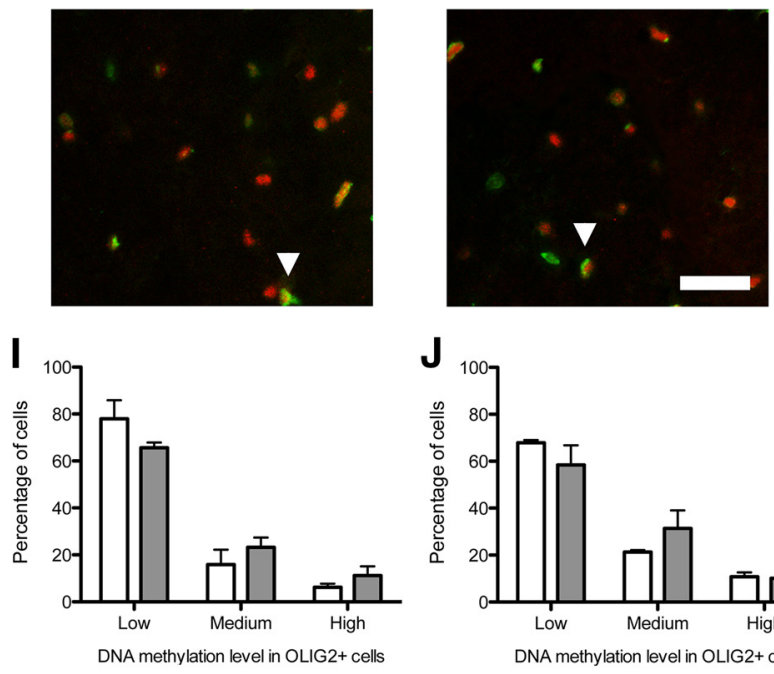

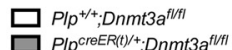

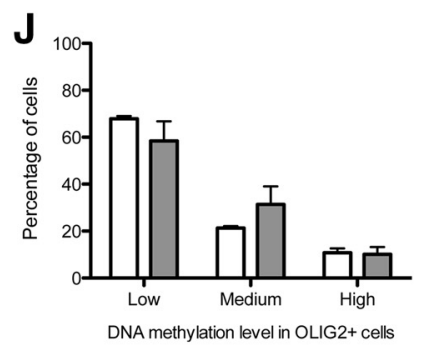

$\square P / p^{+/+} ; D n m t 1^{f / l f l} ; D n m t 3 a^{a / l f i}$

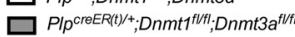


Figure 2. Ablation of Dnmt1 or Dnmt3a does not impair oligodendrocyte differentiation or their methylation levels in control conditions. $\boldsymbol{A}$, Representative OLIG2 and CC1 staining in tamoxifen-treated $P / p^{+/+} ; D n m t 1^{f l / f l}$ and $P / p^{c r e E R(t) /+} ; D n m t 1^{f l / f l} \mathrm{NWM}$ spinal cords. $\boldsymbol{B}$, Quantification of OLIG2 ${ }^{+}$and $\mathrm{CC}_{1}{ }^{+}$cell densities in $\mathrm{NWM}^{f}(p=0.3537, p=0.3803)$. $\boldsymbol{C}$, Representative OLIG2 and CC1 staining in tamoxifen-treated $P / p^{+/+} ; D n m t 3 a^{f l / f l}$ and $P / p^{c r e E R(t) /+} ; D n m t 3 a^{f l / f l}$ NWM spinal cords. D, Quantification of OLIG2 ${ }^{+}$and CC1 ${ }^{+}$cell densities in $\mathrm{NWM}^{9}(p=0.8926, p=0.5109)$. $E$, Representative OLIG2 and CC1 staining in tamoxifen-treated $P / p^{+/+} ;$Dnmt $1^{f l / f l}$; Dnmt3a $a^{f l / f l}$ and Plp ${ }^{c r e E R(t) /+} ; D n m t 1^{f l / f l} ; D n m t 3 a^{f l / f l}$ NWM spinal cords. $\boldsymbol{F}$, Quantification of OLIG2 ${ }^{+}$and CC1 $1^{+}$cell densities in NWM ${ }^{h}$ $(p=0.3136, p=0.2173)$. G, Representative $5 \mathrm{mC}$ and OLIG2 stainings in tamoxifen-treated $P / p^{c r e E R(t) /+} ; D n m t 1^{f / / f l}, P / p^{c r e E R(t) /+} ; D n m t 3 a^{f l / f l}$, and $P / p^{\text {creER(t)/+}} ;$; Dnmt $1^{f l / f l} ;$ Dnmt3a ${ }^{f l / f l}$ NWM spinal cords (white arrowheads indicate high-5mC ${ }^{+} / \mathrm{OLIG}^{+}$cells). $\boldsymbol{H}$, Quantification of low-, medium-, and high-5mC levels in OLIG2 ${ }^{+}$cells in tamoxifen-treated $P / p^{+/+} ;$Dnmt $1^{f l / f l}$ and $P / p^{\text {creER(t)/++}}$;Dnmt $1^{f l / f l} \mathrm{NWM}^{\mathrm{j}}$. I, Quantification of low-, medium-, and high-5mC levels in OLIG2 ${ }^{+}$cells in tamoxifen-treated $P / p^{+/+} ; D n m t 3 a^{f / f l}$ and $P / p^{c r e E R(t) /+}$; Dnmt3a $a^{f / f l}$ NWMij. J, Quantification of low-, medium-, and high-5mC levels in OLIG ${ }^{+}$cells in tamoxifen-treated Plp ${ }^{+/+} ; D n m t 1^{f l / f l}$; Dnmt3a $a^{f l / f l}$ and $P / p^{c r e E R(t) /+} ; D n m t 1^{f l / f l} ; D n m t 3 a^{f l / f l}$ NWM $^{k}$. Scale bar $=50 \mu \mathrm{m}$. Data are mean \pm SEM. $n=4-6$ animals, three sections per animal (Student's t test, ANOVA).

crossed the Dnmt $1^{f / / f l}$ and Dnmt3a $a^{f / / f l}$ lines with the inducible Plp-creER(t), to target specific ablation of Dnmt1, Dnmt3a, or both Dnmt1 and Dnmt3a in proteolipid protein (PLP)-expressing oligodendroglial cells after lysolecithininduced demyelination. All three mutants $\left(P / p^{\text {creER(t)/++ }}\right.$ :

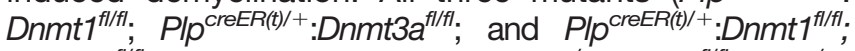

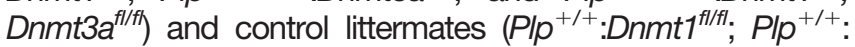
Dnmt3a ${ }^{\text {fl/ff }}$ and $\mathrm{Plp}^{+/+}: D n m t 1^{f / / f l} ;$ Dnmt3a $a^{f / / f)}$ ) were gavaged with tamoxifen at 3,5 , and $7 \mathrm{dpl}$ and then lesioncontaining tissue harvested at $14 \mathrm{dpl}$ and processed for immunohistochemistry using antibodies specific for $5 \mathrm{mC}$, for mature oligodendrocytes (CC1), or for all cells within the oligodendrocyte lineage (OLIG2).

We first quantified the number of OLIG2 ${ }^{+}$and $\mathrm{CC}_{1}{ }^{+}$in NWM to address the effect of Dnmt1 and/or Dnmt3a ablation itself on the generation of OPCs and OLs (Fig. $2 A-F$ ). We detected no difference in the number of $\mathrm{OLIG}^{+}$and $\mathrm{CC}^{+}{ }^{+}$cells in any knock-out compared with control NWM (Fig. 2B, D, F). Moreover, there was no differences in $5 \mathrm{mC}$ expression levels in $\mathrm{OLIG}^{+}$cells in knock-out compared with control NWM (Fig. 2G-J).

At $14 \mathrm{dpl}$, there was no difference in the number of $\mathrm{OLIG}^{+}$and $\mathrm{CC}^{+}{ }^{+}$cells in the lesion or in the percentage of $\mathrm{CC}_{1}{ }^{+}$differentiated $\mathrm{OL}$ among the $\mathrm{OLIG}{ }^{+}$oligodendroglial cells between $\mathrm{Plp}^{+/+} ; \mathrm{Dnmt}{ }^{f / / f l}$ controls and

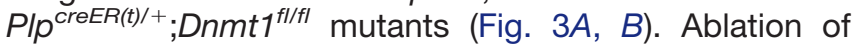
Dnmt3a resulted in a significant decrease of the percentage of $\mathrm{CC}_{1}{ }^{+}$differentiated OL among the OLIG2 ${ }^{+}$oligodendroglial cells (Fig. $3 C, D$ ). This indicated that OPC differentiation was altered in mutants lacking Dnmt3a, whereas $\mathrm{OLIG}^{+}$proliferation and recruitment to the lesion was not affected (Fig. 3D). It was noteworthy that increased DNMT1 levels were detected in $\mathrm{CC}_{1}{ }^{+}$cells in $P / p^{\text {creER(t)/+ }} ;$ Dnmt3a $a^{f / f l}$ mutant spinal cords, suggesting that in the absence of DNMT3A there might be a compensatory increase in DNMT1 (Fig. 3G). To offset this possible effect, we performed a similar analysis on double knockout mice lacking both Dnmt1 and Dnmt3a. Both the number of $\mathrm{CC}^{+}$cells in the lesion and the percentage of $\mathrm{CC}^{+}$differentiated $\mathrm{OL}$ among the $\mathrm{OLIG}{ }^{+}$oligodendroglial cells were decreased in the double $\left(P / p^{\text {creER(t)/+ }}\right.$ : $\left.D n m t 1^{f l / f l} ; D n m t 3 a^{f \mid l f f}\right)$ mutants, and to a greater extent than we observed in the Dnmt3a-only ablated $\left(P / p^{\text {creER(t)/+ }}\right.$; Dnmt3a $\left.{ }^{f \mid l f l}\right)$ mutants (Fig. 3E, F).

There were no changes in $5 \mathrm{mC}$ expression levels in

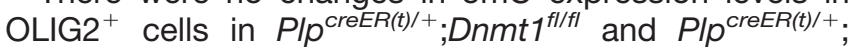
Dnmt3a ${ }^{f l / f l}$ mutants (Fig. $4 A-D$ ). However, there was an increase in the percentage of low-5mC-expressing $\mathrm{OLIG}^{+}$cells, associated with a decrease of medium$5 \mathrm{mC}$-expressing OLIG2 ${ }^{+}$cells in the double Plp $\mathrm{p}^{\mathrm{creER}(t) /+}$ : Dnmt $1^{f l / f} ;$;Dnmt3a $a^{f / f l}$ mutants (Fig. 4E, F). This suggested an increase in low-methylated and a decrease in mediummethylated oligodendroglial cells in Dnmt1/Dnmt3a ablated mutants, which contrasted with the increased methylation previously observed in control animals (Fig. $1 H, I)$.

These data indicate a role for DNMT3A in adult OPC differentiation during remyelination that can be compensated for by DNMT1.

\section{Ablation of Dnmt1 and Dnmt3a impairs remyelination in the adult spinal cord}

To establish whether the impaired differentiation of OPC lacking DNMTs affected remyelination, we used a similar experimental design where we killed lesioned control and mutant mice at $21 \mathrm{dpl}$ and evaluated remyelination by light microscopic examination of semithin resin sections stained with toluidine blue and by electron microscopy. Comparison of control and mutant NWM revealed no abnormalities in myelination in the three knockout mouse lines (data not shown). Ranking of remyelination on semithin sections (Fig. $3 A, B, D, E$ ) and quantification of the g-ratio (Fig. $3 C, F$ ) did not reveal any differences from controls for either Dnmt1- or Dnmt3a-ablated mice. In contrast, despite a similar ranking of remyelination in sections from controls and double mutants (both Dnmt1 and Dnmt3a ablated; Fig. 3G, H, J), the quantification of $g$-ratio revealed thinner myelin in mutants, likely suggesting delayed remyelination in the absence of Dnmt1 and Dnmt3a (Fig. 3). This suggests that if Dnmt3aonly ablation is sufficient to reduce adult OPC differentiation in a lysolecithin-induced lesion, compensation by DNMT1 might prevent significantly delayed remyelination.

These data demonstrate that dysregulation of DNA methylation in adult oligodendroglial cells impairs their differentiation and hence their ability to contribute to remyelination.

\section{Discussion}

Here we report that DNMT1 and DNMT3A are differentially expressed during remyelination after lysolecithininduced demyelination in the adult spinal cord, with DNMT1 being highly expressed in OPCs at early time points after demyelination (corresponding in this model to the early stages of remyelination) and DNMT3A being highly expressed in $\mathrm{OL}$ at later time points (corresponding 
A

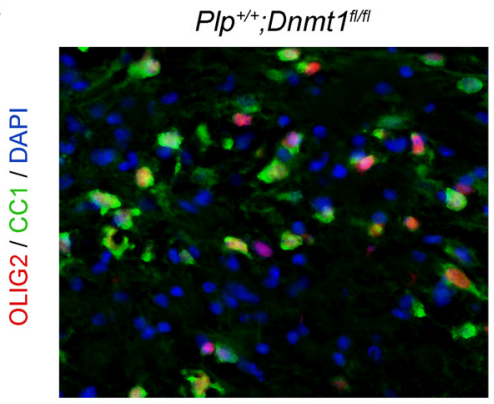

C

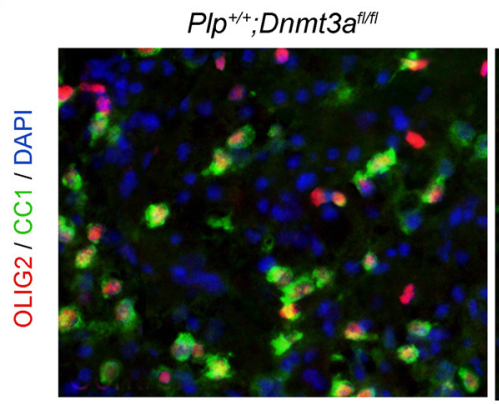

E

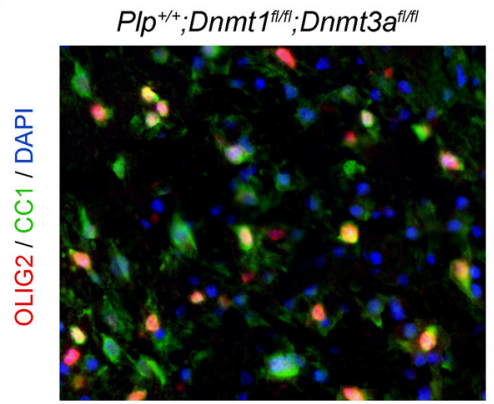

G

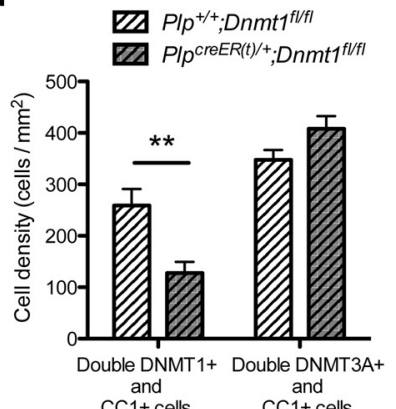

$P / p^{\text {creER }(t) /+}: D n m t 1^{\text {fl/fil }}$

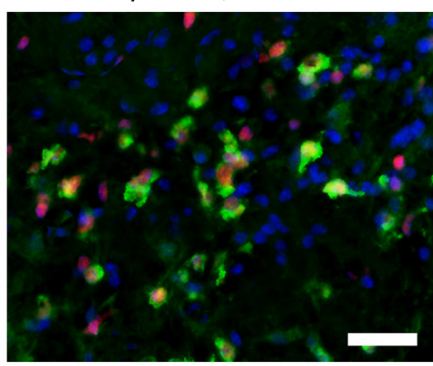

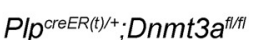

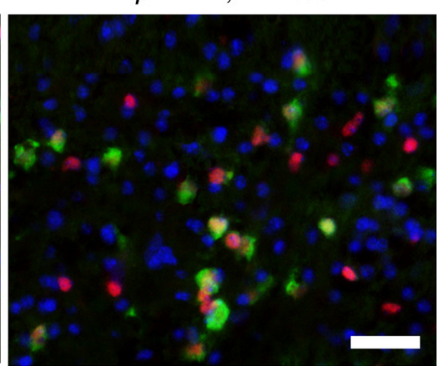

$P \mid p^{\text {creER }(t) /+} ; D n m t 1^{f|f| t \mid} ; D n m t 3 a^{f / f t}$

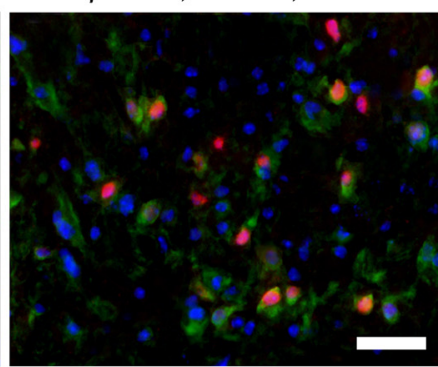

B

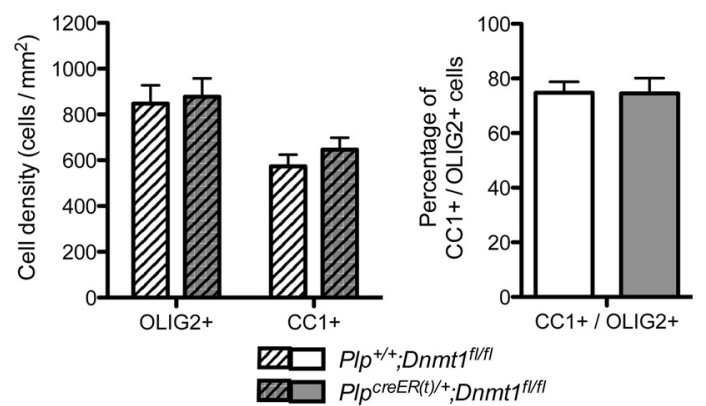

D

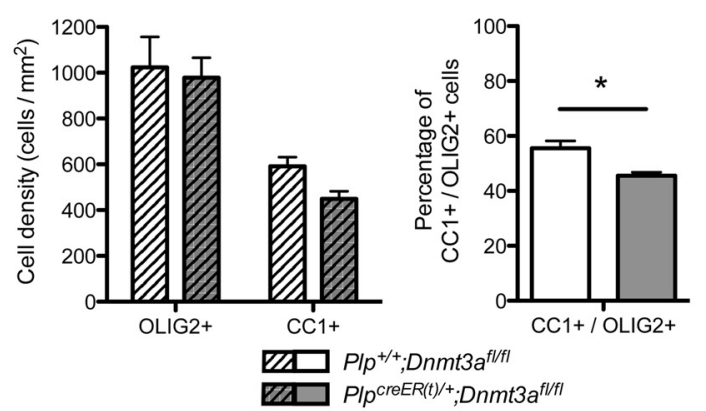

$\mathbf{F}$

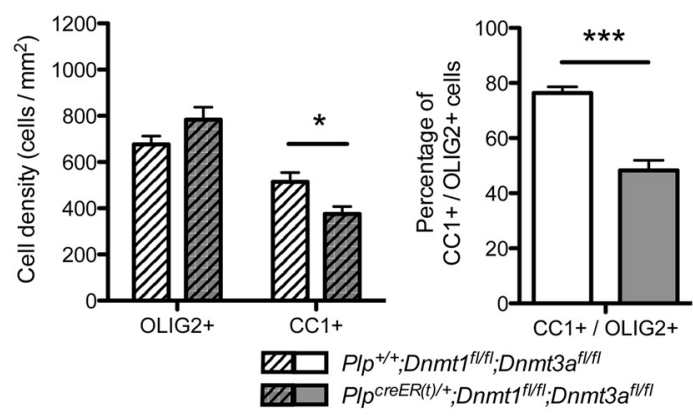

Figure 3. Ablation of Dnmt3a and both Dnmt1 and Dnmt3a impairs oligodendrocyte differentiation during remyelination. $\boldsymbol{A}$,

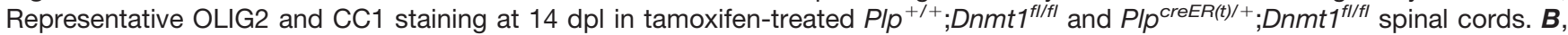
Quantification of $\mathrm{OLIG} 2^{+}$and $\mathrm{CC} 1^{+}$cell densities and CC1 ${ }^{+} / \mathrm{OLIG} 2^{+}$cells percentage at $14 \mathrm{dpl}(p=0.7955, p=0.3573, p=0.9689)$. C, Representative OLIG2 and CC1 staining at $14 \mathrm{dpl}$ in tamoxifen-treated $P / p^{+/+} ;$Dnmt $3 a^{f l / f l}$ and $P / p^{c r e E R(t) /+} ;$ Dnmt3a $a^{f l / f l}$ spinal cords. $\boldsymbol{D}$, Quantification of $\mathrm{OLIG} 2^{+}$and $\mathrm{CC} 1^{+}$cell densities and $\mathrm{CC} 1^{+} / \mathrm{OLIG} 2^{+}$cells percentage at $14 \mathrm{dpl}{ }^{\mathrm{m}}(p=0.7851, p=0.0550, p=$ 0.0149). E. Representative OLIG2 and CC1 staining at $14 \mathrm{dpl}$ in tamoxifen-treated $P / p^{+/+} ; D n m t 1^{f l / f l} ; D n m t 3 a^{f / f l}$ and $P / p^{c r e E R(t) /+}$; $D n m t 1^{f l / f l} ; D n m t 3 a^{f l / f l}$ spinal cords. $\boldsymbol{F}$, Quantification of OLIG2 ${ }^{+}$and $C C 1^{+}$cell densities and CC $1^{+} / O L I G 2^{+}$cells percentage at 14 dpI ${ }^{\mathrm{I}}$ $(p=0.1510, p=0.0357, p=0.0006)$. G, Quantification of DNMT1 and DNMT3A expression in CC1 ${ }^{+}$cells at 14 dpl in tamoxifen-treated $P / p^{+/+} ; D n m t 1^{f l / f l}$ and $P / p^{c r e E R(t) /+} ; D n m t 1^{f l f l}, P^{\prime} p^{+/+} ; D n m t 3 a^{f l / f l}$ and Plp ${ }^{c r e E R(t) /+} ; D n m t 3 a^{f l / f l}, P l p^{+/+} ; D n m t 1^{f l / f l}$; $D n m t 3 a^{f l / f l}$ and $P / p^{c r e E R(t) /+} ; D n m t 1^{f l / f l} ; D n m t 3 a^{f l / f l}$ spinal cords, to detect eventual compensation between DNMTs at the protein level ${ }^{\circ}$ $(p=0.0075, p=0.0505, p=0.0074, p=0.0053, p=0.0072, p=0.0012)$. Scale bar $=20 \mu \mathrm{m}$. Data are mean \pm SEM. $n=4-6$ animals, three sections per animal. $* p<0.05, * * p<0.01, * * * p<0.001$ (Student's $t$ test). 
A

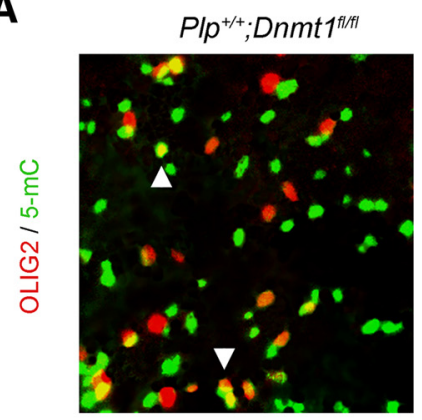

C

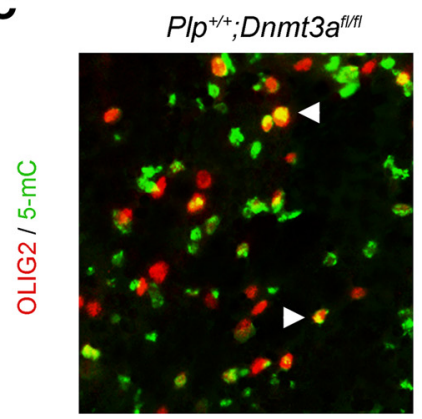

E

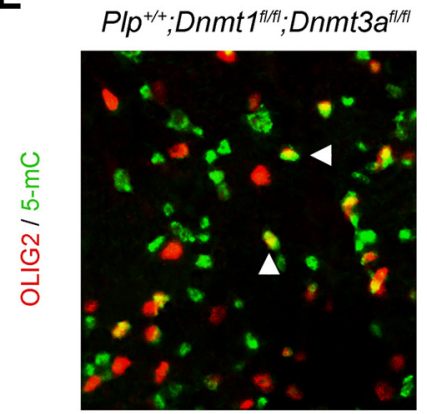

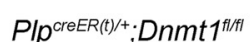

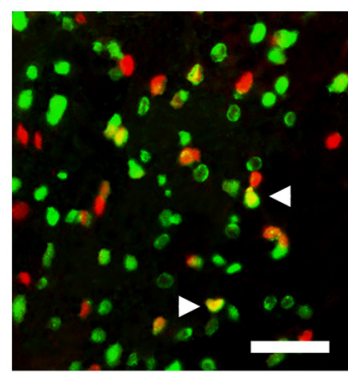

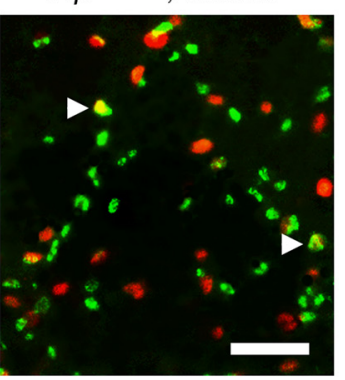

B

14dpl

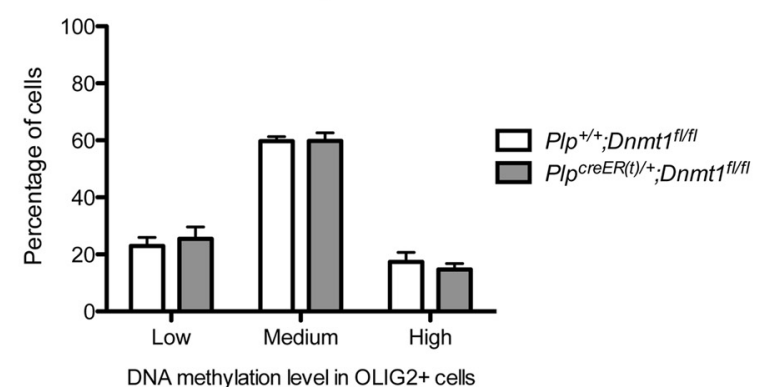

D

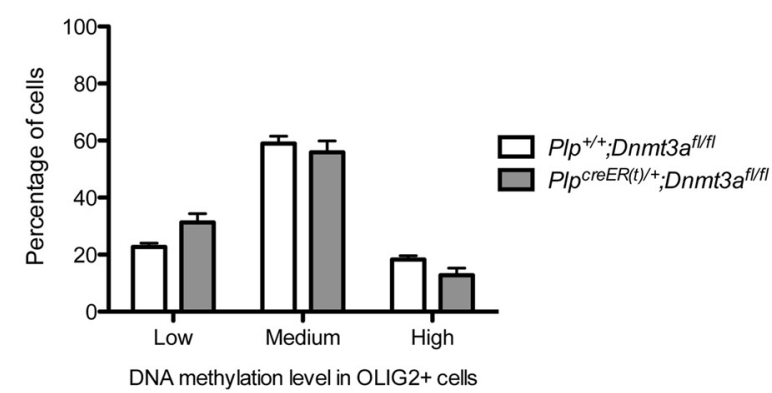

$\mathbf{F}$

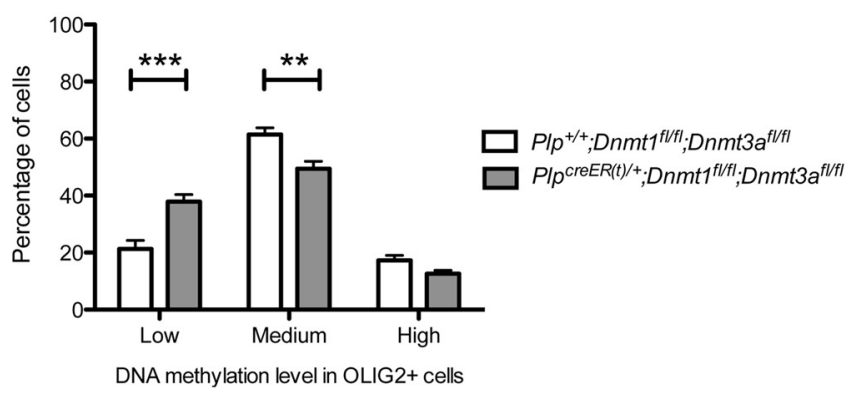

Figure 4. Ablation of Dnmt3a and both Dnmt1 and Dnmt3a impairs methylation levels in oligodendroglial cells during remyelination. $\boldsymbol{A}$, Representative $5 \mathrm{mC}$ and OLIG2 staining at $14 \mathrm{dpl}$ in tamoxifen-treated $P / p^{+/+} ; D n m t 1^{f l / f l}$ and $P / p^{c r e E R(t) /+}$;Dnmt $1^{f / f l}$ spinal cords (white arrowheads indicate high- $5 \mathrm{mC}^{+} / \mathrm{OLIG} 2^{+}$cells). B, Quantification of low-, medium-, and high-5mC levels in OLIG2 ${ }^{+}$cells at 14dpl ${ }^{\mathrm{P}}$. C, Representative $5 \mathrm{mC}$ and OLIG2 staining at $14 \mathrm{dpl}$ in tamoxifen-treated $P / p^{+/+} ;$Dnmt $^{f / f l}$ and $P / p^{c r e E R(t) /+} ; D n m t 3 a^{f / f l}$ spinal cords (white arrowheads indicate high- $5 \mathrm{mC}^{+} / \mathrm{OLIG}^{+}$cells). $\boldsymbol{D}$, Quantification of low-, medium-, and high-5mC levels in OLIG2 ${ }^{+}$cells at $14 \mathrm{dpl}^{q}$. E, Representative $5 \mathrm{mC}$ and OLIG2 staining at $14 \mathrm{dpl}$ in tamoxifen-treated $P / p^{+/+} ; D n m t 1^{f l f f}$ and $P / p^{c r e E R(t) /+} ; D n m t 1^{f l / f l}$; $D n m t 3 a^{f l f l}$ spinal cords (white arrowheads indicate high- $5 \mathrm{mC}^{+} / \mathrm{OLIG}^{+}$cells). $\boldsymbol{F}$, Quantification of low-, medium-, and high-5mC levels in OLIG2 ${ }^{+}$cells at $14 \mathrm{dpl}^{r}$. Scale bar $=100 \mu \mathrm{m}$. Data are mean \pm SEM. $n=4-6$ animals, three sections per animal. $* * p<0.01$, $* * * p<0.001$ (ANOVA).

to the later stages and completion of remyelination). These data validate and extend previous microarraygenerated data obtained in laser-capture microdissected tissues from rats with ethidium bromide-induced demyelinating lesions, which revealed initial increased expression of both Dnmt1 and Dnmt3a and their subsequent decrease in expression (Huang et al. 2011). Discordance between the two studies, especially for DNMT3A expression, can be explained by differences in the experimental approach. The Huang et al. (2011) dataset was obtained from whole tissue, which has a mixed composition and percentage of various cell types at different time points, possibly impacting the levels of transcripts. Indeed, Dnmt1 and Dnmt3a are also highly expressed by astro- cytes and microglial cells, the latter being massively abundant in the lesion at $5 \mathrm{dpl}$ but less abundant during later stages (Zhang et al. 2014).

Our study reports global hypermethylation in the nuclei of oligodendroglial lineage cells during remyelination, similar to what was described during developmental myelination (Moyon et al. 2016). These data suggested that adult OPC differentiation might recapitulate their developmental differentiation, by activating the same transcriptional pathways and perhaps the same epigenetic modulators (Fancy et al. 2004, 2009; Koenning et al. 2012; Nakatani et al. 2013; Moyon et al. 2015; Zhao et al. 2015). Indeed, chromatin remodelers (i.e., Chd7 and Brg1) and histone deacetylases have been recently shown to be 
A

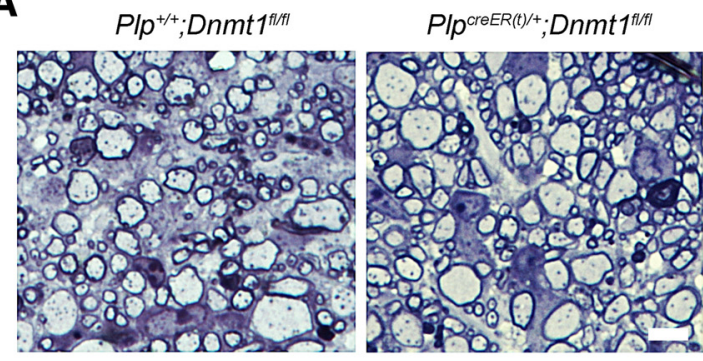

D

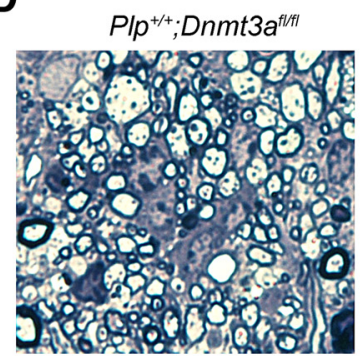

Plp ${ }^{\text {creeR }(t)++} \cdot$ Dnmt3a $a^{f / f i l}$

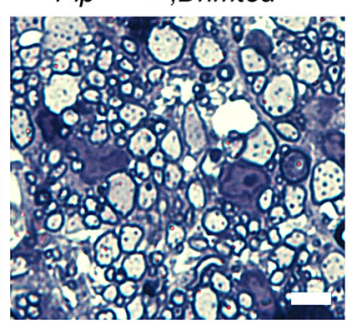

B

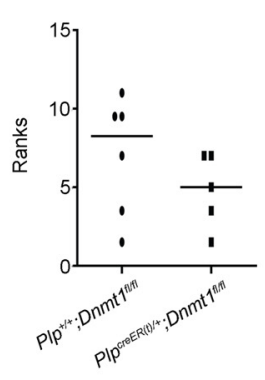

E

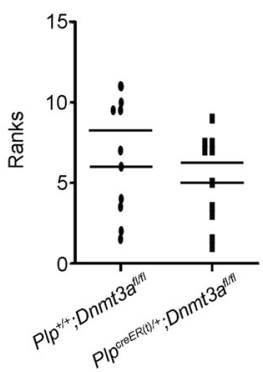

C

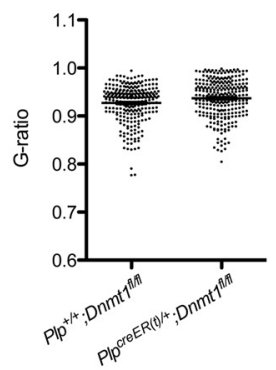

F

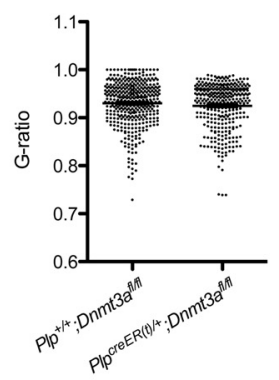

21dpl

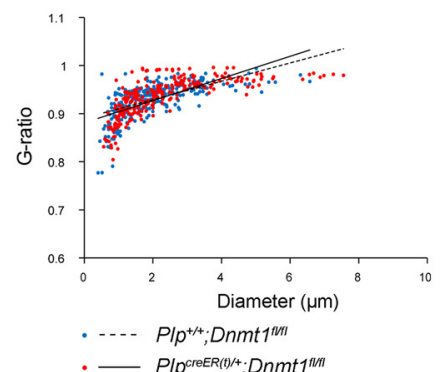

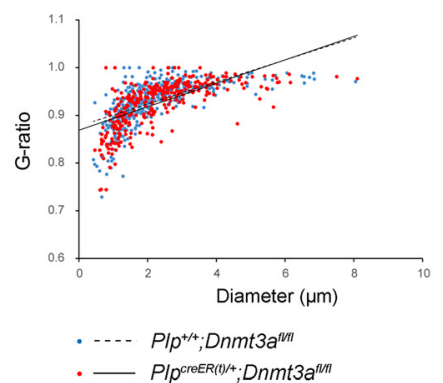

G
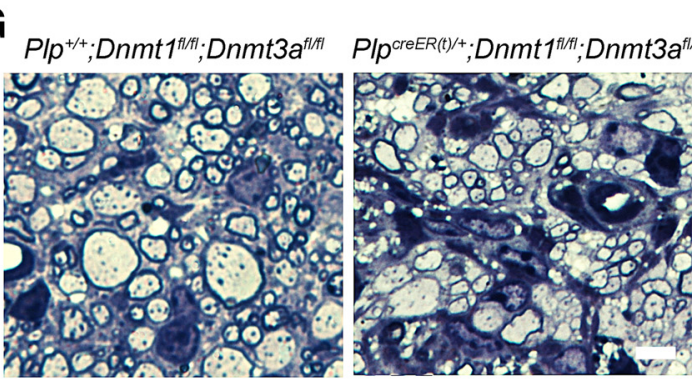

H

I
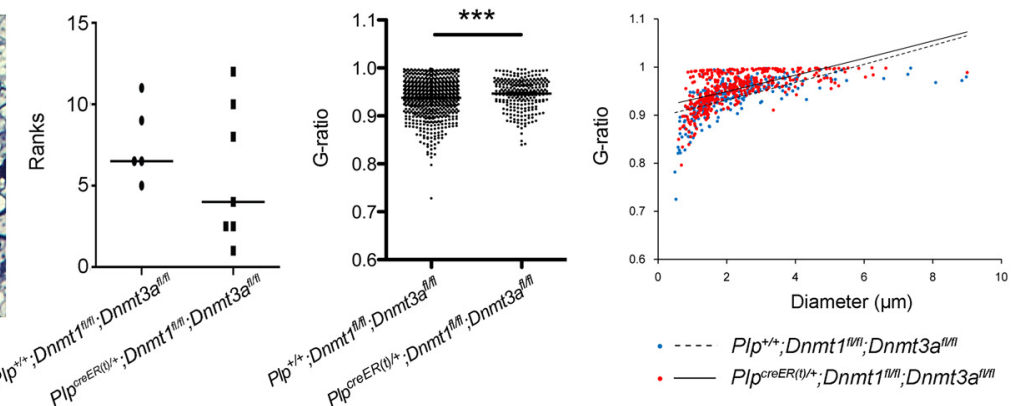

J $P / p^{+/+} ; D n m t 1^{f / f f l} ; D n m t 3 a^{f / f f l} \quad P l p^{c r e E R(t) /+} ; D n m t 1^{f / f / f} ; D n m t 3 a^{f / / f t}$
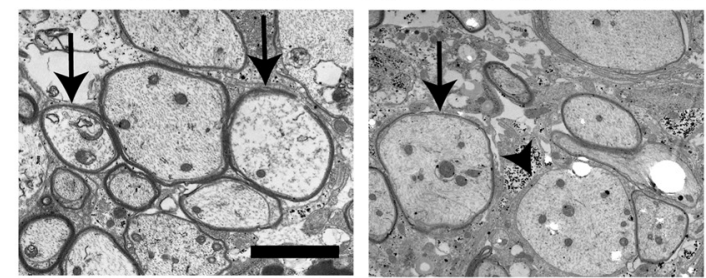

Figure 5. Ablation of Dnmt1 and Dnmt3a impairs remyelination in the adult spinal cord. $\boldsymbol{A}$, Representative semithin sections at $21 \mathrm{dpl}$ in tamoxifen-treated $P / p^{+/+} ; D n m t 1^{f l / f l}$ and $P / p^{c r e E R(t) /+} ; D n m t 1^{f / f f}$ spinal cords. $\boldsymbol{B}$, Relative ranking of remyelination $(p=0.3075)$. $\boldsymbol{C}$, Quantification of g-ratios for control and mutants mice, and plot of g-ratios against axonal diameter ${ }^{t}(p=0.9426)$. $\boldsymbol{D}$, Representative semithin sections at $21 \mathrm{dpl}$ in tamoxifen-treated $P / p^{+/+} ; D n m t 3 a^{f l / f l}$ and $P / p^{c r e E R(t) /+} ; D n m t 3 a^{f l / f l}$ spinal cords. E, Relative ranking of remyelination ${ }^{\mathrm{u}}(p=0.7144)$. $\boldsymbol{F}$, Quantification of g-ratios for control and mutants mice, and plot of g-ratios against axonal diameter ${ }^{\mathrm{v}}$ $(p=0.1079)$. G. Representative semithin sections at $21 \mathrm{dpl}$ in tamoxifen-treated $P / p^{+/+} ;$Dnmt $1^{f l / f l} ;$ Dnmt3a $a^{f / / f l}$ and $P / p^{c r e E R(t) /+} ;$;Dnmt $1^{f / / f l}$; $D_{n m} a^{f l / f l}$ spinal cords. $\boldsymbol{H}$, Relative ranking of remyelination $\times(p=0.7584)$. I, Quantification of g-ratios for control and mutants mice, and plot of g-ratios against axonal diameter ${ }^{y}(p=0.0005)$. $\boldsymbol{J}$, Representative electron microscopic sections at $21 \mathrm{dpl}$ in tamoxifentreated $P / p^{+/+} ; D n m t 1^{f l f f l} ; D n m t 3 a^{f l / f l}$ and $P / p^{c r e E R(t) /+} ; D n m t 1^{f l / f l} ; D n m t 3 a^{f l / f l}$ spinal cords revealing new thin myelin sheaths of remyelination (arrows) and a demyelinated axon (arrowhead). Scale bar $=10 \mu \mathrm{m}$. Dots are ranking for each mouse $(\boldsymbol{B}, \boldsymbol{E}, \boldsymbol{H})$ and $\mathrm{g}-\mathrm{ratio}$ for each quantified axon $(\boldsymbol{C}, \boldsymbol{F}, \boldsymbol{I})$. Data are mean \pm SEM. $n=3-5$ animals, $>70$ axons per animal. $* * * p<0.01$ (Mann-Whitney test and Student's $t$ test).

essential for OPC myelination as well as remyelination (Shen et al. 2008; He et al. 2016).

Using conditional knockout murine strains, we showed that lack of Dnmt3a, and not Dnmt1, in oligodendroglial cells impairs adult OPC differentiation. These data differed from the findings obtained during development, when the ablation of Dnmt1, and not Dnmt3a, resulted in extensive defective myelination of the CNS (Moyon et al. 
2016). We also observed that, contrary to developmental data, loss of Dnmt3a was partially compensated for by upregulation of Dnmt1 levels, leading to decreased adult OPC differentiation and remyelination delays in the double conditional knockout mice. It is important to highlight that the $P / p-c r e E R(t)$ line was used to target oligodendroglial lineage in an inducible manner in the adult spinal cord. Although PLP has been shown to be expressed in adult OPCs (Spassky et al. 1998; Ruffini et al. 2004; Lin et al. 2009), our ablation of Dnmt1 and Dnmt3a may have targeted a more mature population, when cells have already exited the cell cycle, and thus when DNMT1 and DNMT3A might have a different impact. The remyelination delay observed here is also less drastic than the extensive and global hypomyelination affecting the Olig $1^{\mathrm{cre} /+} ; D n m t 1^{f / / f l}$ mutant mice (Moyon et al. 2016). Adult OPCs tend to proliferate less than their neonatal counterparts, suggesting that the absence of DNMT1 may not as adversely affect their replication, cell division, and survival (Wolswijk and Noble, 1989; Wolswijk et al. 1991; Shi et al. 1998; Ruffini et al. 2004; Lin et al. 2009; Young et al. 2013; Moyon et al. 2015). Moreover, some epigenetic marks might have been already established and could be irreversibly maintained in adult OPCs, which are emerging from a pool of undifferentiating neonatal OPCs (Zawadzka et al. 2010). Indeed, it has been shown that in cell lines epigenetic markers such as histone methylation, histone deacetylation, and DNA methylation might have specific dynamics, with some being partial committers and others complete committers, depending on their enzyme recruitment speed and affinity at specific genomic sites (Bintu et al. 2016). For example, the de novo embryonic DNMT3B is a slow silencer but complete committer, as its methylated marks could not be easily removed. Thus, it could explain why ablation of Dnmt3a in adult OPCs might have a limited effect and only delay remyelination, as its markers would be maintained long after the enzyme ablation.

Finally, DNA methylation has been shown to be dysregulated in several neurologic pathologies, including amyotrophic lateral sclerosis, schizophrenia, and oligodendroglial pathologies such as MS and gliomas (Chou et al. 2012; Martin and Wong, 2013; Huynh et al. 2014; Hannon et al. 2016; Jaffe et al. 2016). In addition to neuropathy, dementia, and hearing loss, patients with DNA methyltransferase (DNMT1) mutations present with mild CNS hypomyelination (Klein et al. 2011). Epigenomewide methylation study has identified several hypermethylated or hypomethylated loci in MS patient postmortem brain tissues compared with controls (Huynh et al. 2014) and several studies in gliomas have described an extensive global DNA hypomethylation (Watanabe and Maekawa, 2010; Chou et al. 2012) associated with site-specific DNA hypermethylation (Felsberg et al. 2006; Sharma et al. 2010). Further epigenome-wide studies should be performed on adult OPCs to specifically identify genomic loci that might be hypo- or hypermethylated during their proliferation and their differentiation, in control conditions and after demyelination or in gliomas. We propose that modulating DNA methylation in oligodendroglial cells could efficiently regulate adult OPC proliferation and differentiation capacities. Targeting DNA methylation at specific genomic loci, using engineered zinc fingers or CRISPR-Cas9 methylation modulators, might lead to the development of new therapeutic strategies in gliomas and MS (Choudhury et al. 2014; Heller et al. 2014; McDonald et al. 2016).

\section{References}

Bintu L, Yong J, Antebi YE, McCue K, Kazuki Y, Uno N, Oshimura M, Elowitz MB (2016) Dynamics of epigenetic regulation at the singlecell level. Science 351:720-724. CrossRef

Chou AP, Chowdhury R, Li S, Chen W, Kim AJ, Piccioni DE, Selfridge JM, Mody RR, Chang S, Lalezari S, et al. (2012) Identification of retinol binding protein 1 promoter hypermethylation in isocitrate dehydrogenase 1 and 2 mutant gliomas. J Natl Cancer Inst 104: 1458-1469. CrossRef

Choudhury SR, Cui Y, Lubecka K, Stefanska B, Irudayaraj J (2014) CRISPR-dCas9 mediated TET1 targeting for selective DNA demethylation at BRCA1 promoter. Oncotarget 7:46545-46556.

Doerflinger NH, Macklin WB, Popko B (2003) Inducible site-specific recombination in myelinating cells. Genes 35:63-72. CrossRef

Dubois-Dalcq M, Williams A, Stadelmann C, Stankoff B, Zalc B, Lubetzki C (2008) From fish to man: understanding endogenous remyelination in central nervous system demyelinating diseases. Brain 131:1686-1700. CrossRef

Fan G, Beard C, Chen RZ, Csankovszki G, Sun Y, Siniaia M, Biniszkiewicz D, Bates B, Lee PP, Kuhn R, et al. (2001) DNA hypomethylation perturbs the function and survival of CNS neurons in postnatal animals. J Neurosci 21:788-797.

Fancy SPJ, Zhao C, Franklin RJM (2004) Increased expression of Nkx2.2 and Olig2 identifies reactive oligodendrocyte progenitor cells responding to demyelination in the adult CNS. Mol Cell Neurosci 27:247-254. CrossRef

Fancy SP, Baranzini SE, Zhao C, Yuk DI, Irvine KA, Kaing S, Sanai N, Franklin RJM, Rowitch DH (2009) Dysregulation of the Wnt pathway inhibits timely myelination and remyelination in the mammalian CNS. Genes Dev 23:1571-1585. CrossRef

Felsberg J, Yan PS, Huang TH-M, Milde U, Schramm J, Wiestler OD, Reifenberger G, Pietsch T, Waha A (2006) DNA methylation and allelic losses on chromosome arm $14 \mathrm{q}$ in oligodendroglial tumours. Neuropathol Appl Neurobiol 32:517-524. CrossRef

Franklin RJM, ffrench-Constant C (2008) Remyelination in the CNS: from biology to therapy. Nat Rev Neurosci 9:839-855. CrossRef Medline

Franklin RJM, ffrench-Constant C, Edgar JM, Smith KJ (2012) Neuroprotection and repair in multiple sclerosis. Nat Rev Neurol 8:624-634. CrossRef Medline

Hannon E, Spiers H, Viana J, Pidsley R, Burrage J, Murphy TM, Troakes C, Turecki G, O'Donovan MC, Schalkwyk LC, et al. (2016) Methylation quantitative trait loci in the developing brain and their enrichment in schizophrenia-associated genomic regions. Nat. Neurosci 19:48-54. CrossRef

He D, Marie C, Zhao C, Kim B, Wang J, Deng Y, Clavairoly A, Frah M, Wang $\mathrm{H}$, He X, et al. (2016) Chd7 cooperates with Sox10 and regulates the onset of CNS myelination and remyelination. Nat Neurosci 19:678-689. CrossRef Medline

Heller EA, Cates HM, Peña CJ, Sun H, Shao N, Feng J, Golden SA, Herman JP, Walsh JJ, Mazei-Robison M, et al. (2014) Locus-specific epigenetic remodeling controls addiction- and depression-related behaviors. Nat Neurosci 17:1720-1727. CrossRef

Huang JK, Jarjour AA, Nait Oumesmar B, Kerninon C, Williams A, Krezel W, Kagechika H, Bauer J, Zhao C, Evercooren AB, et al. (2011) Retinoid X receptor gamma signaling accelerates CNS remyelination. Nat Neurosci 14:45-53. CrossRef

Huynh JL, Garg P, Thin TH, Yoo S, Dutta R, Trapp BD, Haroutunian V, Zhu J, Donovan MJ, Sharp AJ, et al. (2014) Epigenome-wide differences in pathology-free regions of multiple sclerosis-affected brains. Nat. Neurosci 17:121-130. CrossRef 
Ibanez C, Shields SA, Liere P, El-Etr M, Baulieu E-E, Schumacher M, Franklin RJM (2003) Systemic progesterone administration results in a partial reversal of the age-associated decline in CNS remyelination following toxin-induced demyelination in male rats. Neuropathol Appl Neurobiol 30:80-89.

Jackson-Grusby L, Beard C, Possemato R, Tudor M, Fambrough D, Csankovszki G, Dausman J, Lee P, Wilson C, Lander E, et al. (2001) Loss of genomic methylation causes p53-dependent apoptosis and epigenetic deregulation. Nat Genet 27:31-39. CrossRef

Jaffe AE, Gao Y, Deep-Soboslay A, Tao R, Hyde TM, Weinberger DR, Kleinman JE (2016) Mapping DNA methylation across development, genotype and schizophrenia in the human frontal cortex. Nat. Neurosci 19:40-47. CrossRef

Kaneda M, Okano M, Hata K, Sado T, Tsujimoto N, Li E, Sasaki H (2004) Essential role for de novo DNA methyltransferase Dnmt3a in paternal and maternal imprinting. Nature 429:900-903. CrossRef

Klein CJ, Botuyan M-V, Wu Y, Ward CJ, Nicholson GA, Hammans S, Hojo K, Yamanishi H, Karpf AR, Wallace DC, et al. (2011) Mutations in DNMT1 cause hereditary sensory neuropathy with dementia and hearing loss. Nat Genet 43:595-600. CrossRef

Koenning M, Jackson S, Hay CM, Faux C, Kilpatrick TJ, Willingham M, Emery B (2012) Myelin gene regulatory factor is required for maintenance of myelin and mature oligodendrocyte identity in the adult CNS. J Neurosci 32:12528-12542. CrossRef

Lin G, Mela A, Guilfoyle E, Goldman J (2009) Neonatal and adult $\mathrm{O} 4(+)$ oligodendrocyte lineage cells display different growth factor responses and different gene expression patterns. J Neurosci Res 87:3390-3402. CrossRef

Martin LJ, Wong M (2013) Aberrant regulation of DNA methylation in amyotrophic lateral sclerosis: a new target of disease mechanisms. Neurother J Am Soc Exp Neurother 10:722-733. CrossRef

McDonald JI, Celik H, Rois LE, Fishberger G, Fowler T, Rees R, Kramer A, Martens A, Edwards JR, Challen GA (2016) Reprogrammable CRISPR/Cas9-based system for inducing site-specific DNA methylation. Biol Open doi: 10.1242/bio.019067.

Moyon S, Dubessy AL, Aigrot MS, Trotter M, Huang JK, Dauphinot L, Potier MC, Kerninon C, Parsadaniantz SM, Franklin RJM, et al. (2015) Demyelination causes adult CNS progenitors to revert to an immature state and express immune cues that support their migration. J Neurosci 35:4-20. CrossRef

Moyon S, Huynh JL, Dutta D, Zhang F, Ma D, Yoo S, Lawrence R, Wegner M, John GR, Emery B, et al. (2016) Functional characterization of DNA methylation in the oligodendrocyte lineage. Cell Rep 15:748-760. CrossRef

Nakatani H, Martin E, Hassani H, Clavairoly A, Maire CL, Viadieu A, Kerninon C, Delmasure A, Frah M, Weber M, et al. (2013) Ascl1/ Mash1 promotes brain oligodendrogenesis during myelination and remyelination. J Neurosci 33:9752-9768. CrossRef

Nave KA, Trapp BD (2008) Axon-glial signaling and the glial support of axon function. Annu Rev Neurosci 31:535-561. CrossRef Medline
Ruffini F, Arbour N, Blain M, Olivier A, Antel JP (2004) Distinctive properties of human adult brain-derived myelin progenitor cells. Am J Pathol 165:2167-2175. CrossRef

Sharma S, Kelly TK, Jones PA (2010) Epigenetics in cancer. Carcinogenesis 31:27-36. CrossRef Medline

Shen S, Sandoval J, Swiss V, Li J, Dupree J, Franklin RJM, CasacciaBonnefil P (2008) Age-dependent epigenetic control of differentiation inhibitors is critical for remyelination efficiency. Nat Neurosci 11:1024-1034. CrossRef

Shi J, Marinovich A, Barres BA (1998) Purification and characterization of adult oligodendrocyte precursor cells from the rat optic nerve. J Neurosci 18:4627-4636.

Spassky N, Goujet-Zalc C, Parmantier E, Olivier C, Martinez S, Ivanova A, Ikenaka K, Macklin W, Cerruti I, Zalc B, et al. (1998) Multiple restricted origin of oligodendrocytes. J Neurosci 18:83318343. Medline

Trapp BD, Peterson J, Ransohoff RM, Rudick R, Mörk S, Bö L (1998) Axonal transection in the lesions of multiple sclerosis. $N$ Engl $J$ Med 338:278-285. CrossRef Medline

Watanabe Y, Maekawa M (2010) Methylation of DNA in cancer. Adv Clin Chem 52:145-167. Medline

Wolswijk G, Noble M (1989) Identification of an adult-specific glial progenitor cell. Development 105:387-400. Medline

Wolswijk G, Riddle PN, Noble M (1991) Platelet-derived growth factor is mitogenic for O-2Aadult progenitor cells. Glia 4:495-503. CrossRef Medline

Young KM, Psachoulia K, Tripathi RB, Dunn SJ, Cossell L, Attwell D, Tohyama K, Richardson WD (2013) Oligodendrocyte dynamics in the healthy adult CNS: evidence for myelin remodeling. Neuron 77:873-885. CrossRef Medline

Zawadzka M, Rivers LE, Fancy SP, Zhao C, Tripathi R, Jamen F, Young K, Goncharevich A, Pohl H, Rizzi M, et al. (2010) CNSresident glial progenitor/stem cells produce Schwann cells as well as oligodendrocytes during repair of CNS demyelination. Cell Stem Cell 6:578-590. CrossRef

Zhang Y, Chen K, Sloan SA, Bennett ML, Scholze AR, O'Keeffe S, Phatnani HP, Guarnieri P, Caneda C, Ruderisch N, et al. (2014) An RNA-sequencing transcriptome and splicing database of glia, neurons, and vascular cells of the cerebral cortex. J Neurosci 34: 11929-11947. CrossRef

Zhao C, Fancy SPJ, Ffrench-Constant C, Franklin RJM (2008) Osteopontin is extensively expressed by macrophages following CNS demyelination but has a redundant role in remyelination. Neurobiol Dis 31:209-217. CrossRef

Zhao C, Ma D, Zawadzka M, Fancy SPJ, Elis-Williams L, Bouvier G, Stockley JH, Castro GM, de Wang B, Jacobs S, et al. (2015) Sox2 sustains recruitment of oligodendrocyte progenitor cells following CNS demyelination and primes them for differentiation during remyelination. J Neurosci 35:11482-11499. CrossRef 